\title{
Giant cell myocarditis: evidence for the macrophage origin of the giant cells
}

\author{
JM THEAKER, KC GATTER, A HERYET, DJ EVANS*, J O'D McGEE \\ From the University of Oxford, Nuffield Department of Pathology, and *Department of Medicine, \\ John Radcliffe Hospital, Headington, Oxford
}

SUMMARY In order to elucidate the origin of giant cells in giant cell myocarditis a case has been studied immunohistologically using monoclonal antibodies against a variety of antigens, including those associated with muscle and macrophages. The results strongly suggest that the giant cells are derived from macrophages rather than the muscle cells.

Giant cell myocarditis is a rare condition of unknown aetiology, which is usually rapidly fatal. There is a characteristic histological picture with prominent areas of myocardial cell necrosis associated with a florid histiocytic and eosinophilic infiltrate. ${ }^{1}$ Large numbers of giant cells are present in and around the necrotic areas and, in sections longitudinal to the myocardial fibres, the giant cells are occasionally seen in close association with the end of a degenerating fibre. This observation has led to the view that at least some of the giant cells are of myogenic origin. ${ }^{2}$ This has been supported by electron microscopic studies, in which filaments, interpreted as myofibrils, have been found in the giant cells, ${ }^{134}$ and also by the absence of lysozyme, a macrophage associated marker, from the giant cells ${ }^{4}$

This report describes a case of giant cell myocarditis from which fresh tissue was obtained, making it possible to analyse the nature of the giant cells using a panel of monoclonal antibodies directed against a variety of antigens, including those associated with macrophages and muscle cells.

\section{Patient details}

A necropsy was performed on a 27 year old woman within $24 \mathrm{~h}$ of death. She had suffered a three week illness characterised by syncope, chest pain, dyspnoea, and arrhythmias. The heart was enlarged $(540 \mathrm{~g})$ with both left and right ventricular hypertrophy. The myocardium of both ventricles showed blotchy pallor with numerous small areas of apparent necrosis. There was no overt endocarditis or pericarditis.

Accepted for publication 19 September 1984

\section{Material and methods}

Multiple blocks of the heart were taken and fixed in $10 \%$ formol-saline, at $\mathrm{pH} 7 \cdot 4$, followed by dehydration and embedding in paraffin wax. Sections were cut at 3-5 $\mu \mathrm{m}$ and stained with haematoxylin and eosin, elastic van Gieson, phosphotungstic acid haematoxylin, periodic acid Schiff, Giemsa, Ziehl Nielsen, and Gram's stain. Paraffin sections were also stained by an indirect immunoperoxidase technique for lysozyme and $\alpha_{1}$-antitrypsin, using polyclonal antibodies obtained from Behring.

Further blocks were snap frozen in liquid nitrogen. Cryostat sections were collected on gelatinised slides, fixed in acetone at $22^{\circ} \mathrm{C}$, and air dried overnight. These sections were immunostained with the monoclonal antibodies detailed in the Table and their location visualised by an alkaline phosphatase-antialkaline phosphatase technique. ${ }^{10}$

Small sections of heart were also fixed in $4 \%$ glutaraldehyde, washed in phosphate buffered saline at $\mathrm{pH} 7 \cdot 4$, postfixed with osmium tetroxide, and embedded in Emix. Ultrathin sections were cut and stained with uranyl acetate and lead citrate.

Samples of heart, liver, kidney, brain, and pancreas were taken for viral culture.

\section{Results}

\section{LIGHT MICROSCOPY}

Light microscopy of paraffin embedded material showed large areas of necrosis of myocardial fibres associated with a heavy interstitial infiltrate, composed of an admixture of eosinophils, macrophages, lymphocytes, plasma cells, and giant cells. These latter cells were of variable appearance, with some of Langerhans' type and others of foreign body type. 
Monoclonal antibodies used in the study of giant cell myocarditis

\begin{tabular}{lll}
\hline Antibody & Specificity & Source \\
\hline EBM 11 & Anti-macrophages & Prof J O'D McGee \\
KB90 & Anti-macrophages and hairy cells & Dr K Pulford (unpublished) \\
DE.R.11 & Anti-desmin (intermediate filament of muscle cells) & Dr M Osborne \\
UCHTI & Anti-pan T cell & Dr P Beverley \\
OKT8 & Anti-T suppressor/cytotoxic cell & Ortho \\
Anti-Leu 3a & Anti-T helper/inducer cell & Becton-Dickinson \\
Ki67 & Anti-nuclear proliferation antigen & Prof H Stein $^{\mathbf{6} 9}$ \\
\hline
\end{tabular}

Many were contiguous with the ends of myocardial fibres (Fig. 1). The inflammatory infiltrate was diffuse, and granuloma formation was not observed. No bacteria, parasites, fungi, or protozoa were evident with any of the stains used, and no viruses were isolated after tissue culture.

\section{IMMUNOHISTOLOGY}

The most striking finding was that the giant cells were strongly labelled by two monoclonal antibodies previously shown to react with human tissue macrophages (Fig. 2). None of the giant cells showed any labelling with the monoclonal antibody against the muscle associated intermediate filament desmin, although there was strong staining of all the muscle fibres with this antibody (Fig. 3). Of the antilymphoid antibodies, only anti-Leu 3a (helper $\mathrm{T}$ cell) stained the giant cells. This antibody also stained surrounding macrophages, however, which is in keeping with a well recognised cross reactive labelling pattern previously observed with antibodies of this specificity. ${ }^{\prime \prime}$

The mononuclear inflammatory infiltrate sur- rounding the giant cells and necrotic myocardial cells was mainly a mixture of macrophages and $T$ lymphocytes. Differential labelling of the $T$ cells showed a helper to suppressor ratio of about $3 \cdot 5: 1$.

The monoclonal antibody Ki67 showed nuclear labelling of about $10 \%$ of the mononuclear inflammatory cells but gave no staining of either the giant cells or the myocardial fibres.

There was no staining of the giant cells or myocardial fibres with antilysozyme, although weak staining of moderate numbers of mononuclear inflammatory cells was present. There was weak cytoplasmic staining of some of the giant cells with anti- $\alpha_{1}$-antitrypsin.

\section{ELECTRON MICROSCOPY}

The myocardial cells and many of the inflammatory cells were moderately well preserved ultrastructurally. Several giant cells were observed which contained large numbers of cytoplasmic vacuoles but no myofibrils. Giant cells were not seen in immediate proximity to the end of myocardial fibres, although several mononuclear inflammatory cells were, and

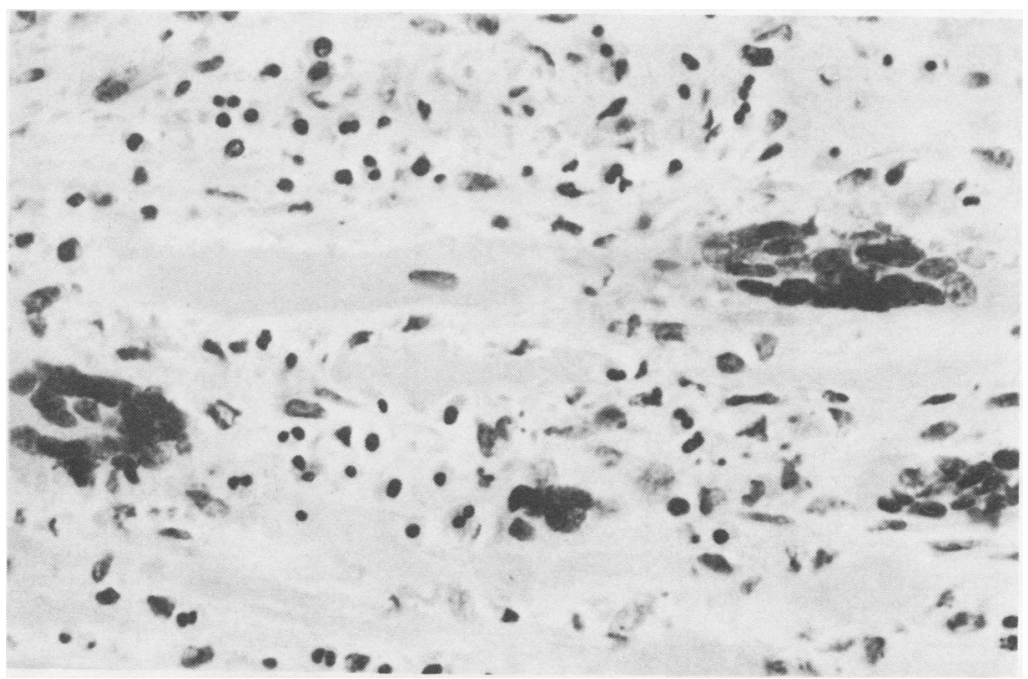

Fig. 1 Representative field of giant cell myocarditis showing characteristic giant cells in close proximity to myocardial fibres and the interstitial inflammatory infiltrate. Haematoxylin and eosin. Original magnification $\times 480$. 


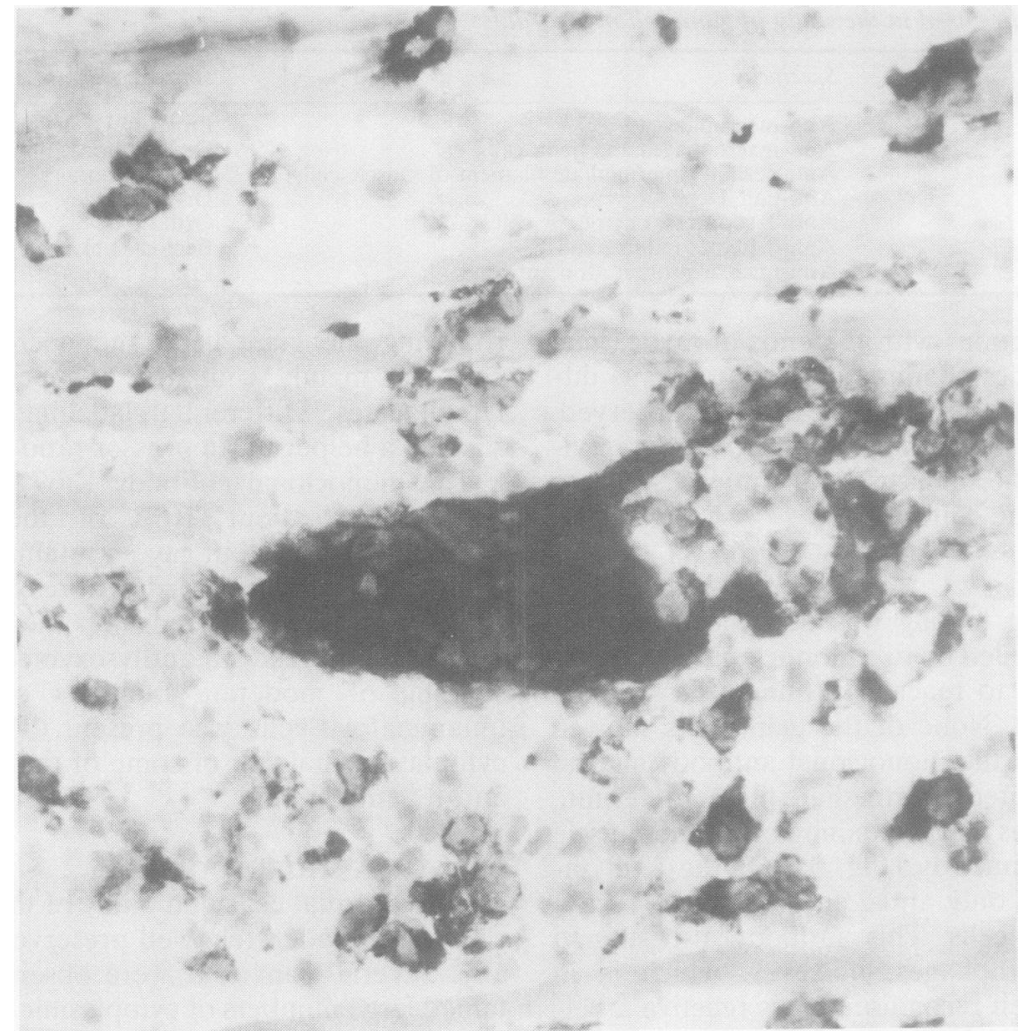

Fig. 2 Giant cell myocarditis stained for EBM11 (recognising a macrophage associated antigen) showing positive labelling of a giant cell and surrounding mononuclear macrophages, but no staining of the myocardial fibres.

Immunoalkaline phosphatase. $\times 480$.

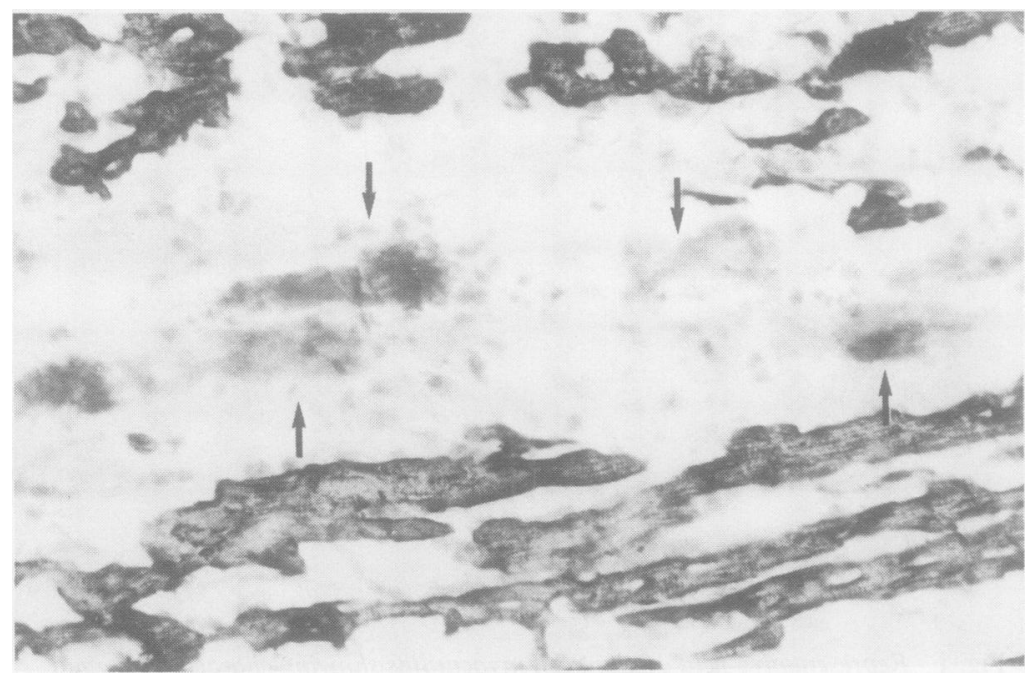

Fig. 3 Giant cell myocarditis stained for desmin intermediate filaments showing positive labelling of the myocardial fibres but no staining of the giant cells (arrows) or other inflammatory cells. Immunoalkaline phosphatase. Original magnification $\times$ 480. 
these also did not contain cytoplasmic myofibrils. No virus particles, other micro-organisms, or electron dense deposits (which may indicate deposition of immune complexes) were apparent in the sections examined.

\section{Discussion}

One of the interesting and controversial aspects of giant cell myocarditis concerns the origin of the characteristic giant cells. Although they may have a macrophage origin, in common with giant cells in other inflammatory conditions, the more widely held view is that they are derived from the damaged myocardial fibres and are therefore myogenic in origin. ${ }^{12}$

The present case of giant cell myocarditis is, to our knowledge, the first in which there has been an opportunity to study this rare condition immunohistologically using monoclonal antibodies. A panel of antibodies against a wide variety of antigens, including those associated with muscle and macrophages, has been used in order to characterise the giant cells.

The immunohistological results are strongly in favour of the view that the giant cells are related to macrophages and not to cardiac muscle cells. In this study the giant cells were positively labelled by two different antimacrophage antibodies, and showed no staining for desmin, the characteristic intermediate filament of muscle. All the myocardial fibres, including those undergoing necrosis, showed strong staining with antidesmin and were completely unreactive with the antimacrophage antibodies. Furthermore, the results with antibody $\mathrm{Ki67}$, which recognises an antigen present in proliferating nuclei, provide additional evidence against a myogenic origin. About $10 \%$ of the inflammatory cells, including both lymphocytes and mononuclear phagocytes, were positive (and thus in the cell cycle), whereas the giant cell and myocardial cell nuclei showed no staining. If the giant cells were regenerating myocardial cells then positive nuclear staining with Ki67 would have been expected. Macrophage derived giant cells are thought to be formed by cell fusion and not by nuclear division ${ }^{13}$ and should therefore give no nuclear staining with Ki67.

Suggestions that the giant cells are of myogenic origin have been based on their close physical association with the myocardial fibres. It is not surprising, however, that macrophage derived giant cells should be in immediate proximity to the ends of damaged myocardial fibres, and in the present study large numbers of interstitial mononuclear macrophages (the presumed precursors of the giant cells) were also identified immunohistologically at this site.
Most electron microscopic studies have been performed on necropsy material, which commonly shows considerable postmortem artefacts, making identification of many ultrastructural features difficult.' In the present case myofibrils were not identified within the cytoplasm of mononuclear macrophages or giant cells and we think that previous observations of this phenomenon may reflect phagocytosis of necrotic myocardial fibres by macrophages.

The absence of lysozyme from the giant cells in the case reported by Tubbs ${ }^{4}$ was taken as evidence of a myogenic origin. It is well recognised, however, that this marker fails to stain some macrophages ${ }^{14}$ so that its absence is a weak argument against a macrophage origin. Indeed, in our case not only the giant cells but also many of the interstitial mononuclear macrophages failed to stain for lysozyme, providing further evidence of its limited value as a macrophage marker.

In conclusion, the present study has shown that the characteristic giant cells in this case of giant cell myocarditis show phenotypic markers of macrophages but do not contain a muscle cell marker. Thus they are probably derived from macrophages. Since the aetiology of this condition is unknown, however, it is possible that the characteristic histological appearances are non-specific and may arise in severe myocarditis of different causes and in other cases the giant cells may be of myogenic origin. Therefore, in order to confirm the results of this study or to provide possible evidence of the heterogeneous nature of giant cell myocarditis, it will be necessary to investigate further cases as they become available, using either necropsy or endomyocardial biopsy material.

We are grateful to those who generously donated the monoclonal antibodies listed in Table 1, to Professor D Grahame-Smith for permission to report this patient, and to Lesley Watts for typing the manuscript.

This study was supported in part by grants from the Wellcome Trust and the Cancer Research Campaign to J O' D McG.

\footnotetext{
References

' Davies MJ, Pomerance A, Teare RD. Idiopathic giant cell myocarditis-a distinctive clinico-pathological entity. $\mathrm{Br}$ Heart J 1975; 37: 192-5.

${ }^{2}$ Whitehead R. Isolated myocarditis. Br Heart J 1965;27:220-30.

${ }^{3}$ Pyun KS, Kim YH, Katzenstein RE, Kikkawa Y. Giant cell myocarditis-light and electron microscopic study. Arch Pathol 1970;90: 181-8.

4 Tubbs RR, Sheibani K, Hawk WA. Giant cell myocarditis. Arch Pathol Lab Med 1980; 104:245-6.
} 
5 Bliss E, Naiem M, Burns J, Bell K, McGee JO' D, Quantitation of macrophages in human breast cancer using monoclonal antibody (EBMII) to human macrophages.J Pathol 1984; 143: A6.

- Debus E, Weber K, Osborn M. Monoclonal antibodies to desmin the muscle-specific intermediate filament protein. $E M B O J$ 1983;2:2305-12.

' Beverley PLC, Callard RE. Distinctive functional characteristics of human T-lymphocytes defined by E-rosetting or a monoclonal anti-T cell antibody. Eur J Immunol 1981;11:329-34.

${ }^{8}$ Gerdes J, Schwab U, Lemke H, Stein H. Production of a mouse monoclonal antibody reactive with a human nuclear antigen associated with cell proliferation. Int J Cancer 1983;31:13-20.

' Gerdes J, Lemke H, Baisch H, Wacker H-H, Schwab U, Stein H. Cell cycle analysis of a cell proliferation associated human nuclear antigen defined by the monoclonal antibody $\mathrm{Ki}-67 . J$ Immunol 1984 (in press).

${ }^{10}$ Cordell JL, Falini B, Erber WN, et al. Immunoenzymatic labeling of monoclonal antibodies using immune complexes of alkaline phosphatase and monoclonal anti-alkaline phosphatase. J Histochem Cytochem 1984;32:219-29.

"Pulford KAF, Knight PM, Gatter KC, Mason DY. Immunocytochemical characteristics of monoclonal antileucocyte antibodies. In: Bernard A, Boumsell L, Dausset J, Milstein C, Schlossman SF, eds. Leucocyte typing. New York: Springer-Verlag, 1983:453-65.

${ }_{12}$ Davies MJ. The cardiomyopathies: a review of terminology, pathology and pathogenesis. Histopathology 1984;8:363-93.

${ }^{13}$ Chambers TJ. Multinucleate giant cells. J Pathol 1978; 126: 125-48.

14 Mason DY, Taylor CR. The distribution of muramidase (lysosyme) in human tissues. J Clin Pathol 1975;28:124-32.

Requests for reprints to: Dr JM Theaker, Nuffield Department of Pathology, John Radcliffe Hospital, Headington, Oxford OX3 9DU, England. 